\title{
Mystery Shopping: Measurement Tool for Customer Intelligence Management
}

\author{
Ms. Priyanka Singh ${ }^{1}$, Mr. Gaurav Verma ${ }^{2}$ \\ ${ }^{1,2}$ (Assistant Professor, Department of Business Administration, Pranveer Singh Institute of Technology, India)
}

\begin{abstract}
Mystery shopping got its start almost a century ago when trained "secret shoppers" were used to anonymously evaluate a business' operation and to measure employee integrity. The industry has evolved, as have the names used to describe it: secret shopping, performance monitoring or even customer research. This paper enhances previous conceptualizations of customer image and perception by introducing the concept referred to as Customer Intelligence management and its tool as mystery shopping. The exploratory research focused on identifying the concept of customer intelligence management and requirement of trained mystery shop auditors to tap the customer intelligence. The goals of this paper are (1) to discuss the enhanced conceptual and operational benefits of mystery shopping in respect of brand positioning. (2) to discussed the requirement of shop auditor to measure customer intelligence 3) Components constructed to train the shop auditors.

To accomplish these goals, the paper discusses the conceptualization and operationalization of this measurement tool as mystery shopping. Ethical code for this measurement tool and discusses the implications for marketing practitioners by identifying the considerations for evaluating and managing customer-intelligence management.
\end{abstract}

Key words: Customer Intelligence management, mystery shopping, Shop Auditors, Ethical Code, Shopper trainings

\section{Introduction:}

Mystery shopping got its start almost a century ago when trained "secret shoppers" were used to anonymously evaluate a business' operation. It was started by private investigators who secretly monitored a business for employee theft. The industry has evolved, as have the names used to describe it: secret shopping, performance monitoring or even customer research.

\section{Mystery Shopping Concept And Process}

Mystery shopping is conducted in almost every industry, ranging from quick-service and high-end restaurants, hotels and resorts, banks and financial service providers, apartments, convenience stores, chain and specialty retailers, home builders, self-storage facilities, healthcare organizations and grocery stores. Mystery shopping providers help businesses design, implement and evaluate mystery shopping programs, as well as coordinate the assignment of mystery shoppers to conduct shops.

\section{Objective Of Mystery Shopping:}

1. Map Touch Points which generate "The Experience"

2. Attach values to Touch Points "Experience Score"

3. Weight these values by importance the customer places on a given part of the experience

4. Ultimately create benchmarks to develop long term KPI's and monitor Applications for Mystery Shopping

Mystery shopping Companies hire trained professional as "Mystery Shop Auditors", either personally or via electronic modes tries to tap the data on customer services and products. The information is recorded in two ways: 'quantitative', and 'qualitative'. The quantitative portion of the report is the numerical score allocated to each pre-defined criterion. This numerical score can then be used to rank the performance of a single location or service within a larger group, or track the performance of a location or locations over a period of time. The qualitative portion of the report is where the investigator writes, in his or her own words, details of the experience. This gives you a strong reference point for the numerical, quantitative score; and also describes a real, live situation to which employees can easily relate.

At the completion of a mystery shop, you receive a copy of each individual shop, and a statistical report customized to give you information in the precise format you require. 


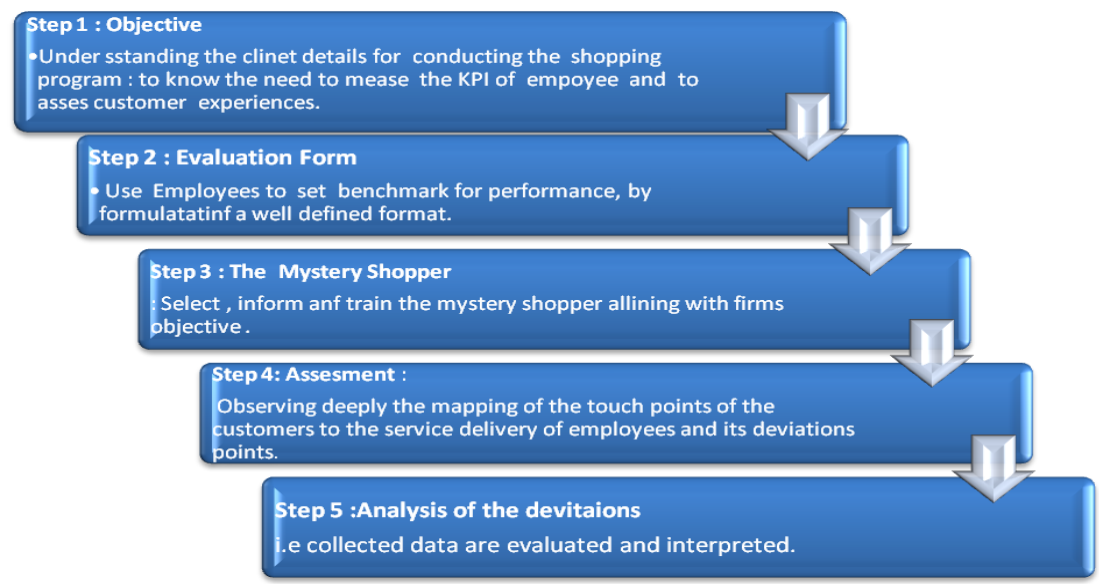

Figure 1 : The Process : Mystery Shopping

\section{Customer Intelligence Management (CIM)}

Consumers have more choices and access to information than ever before, which means your company faces greater competition to garner the sale and to deepen brand loyalty. Thus is the evolution of the concept CIM get . Customer Intelligence is a new, emerging methodology for customer experience insight. Just like business intelligence systems summarize fiscal performance data, customer intelligence gives companies a single, financially accountable view of all their customer-related information. It is and when effectively implemented it is a rich source of insight into the behaviour and experience of a company's customer base. It is a process define as the customer panorama to gather, analyze information around it and generate as perception via experiencing it .

\section{Measurement Tool Of CIM}

Mystery shopping is a tool used for measuring and monitoring customer satisfaction, market research and as a customer experience management tool. Mystery shopping enables firms to audit their own performance in terms of customer service and other parameters

In the dynamic disciplines of Customer Intelligence Management mystery shopping use various modes for services to render to tap the customer experience relating to distinct fields as:

Table 1: The Complete Measurement Tools

\begin{tabular}{|c|c|c|}
\hline & Services Rendered & Its objectivity \\
\hline 1. & $\begin{array}{l}\text { On-Site Mystery } \\
\text { Shopping }\end{array}$ & Objective assessment of the overall operation of each one of the squpp and \\
\hline 2. & $\begin{array}{l}\text { Receipt-Based Web } \\
\text { Customer Satisfaction } \\
\text { Surveys }\end{array}$ & $\begin{array}{l}\text { A web base survey respldting, and the huge cost-efficiencies of delivering a point-of-sale (POS) survey } \\
\text { invitation with each receipt handed out to current customers. }\end{array}$ \\
\hline 3. & Internet Phone Shops & $\begin{array}{l}\text { Achive data results via interaction with custo mer service representatives, sales associates or other } \\
\text { employees on the internet website specifically on "contact Us" page or telephone }\end{array}$ \\
\hline 4. & $\begin{array}{l}\text { Focus Groups/ } \\
\text { Guest Customer } \\
\text { Intercepts }\end{array}$ & $\begin{array}{l}\text { form of qualitative measurement in which a specific group of people are asked about their perceptions, } \\
\text { opinions, beliefs and attitudes towards a product, service, concept, advertisement, idea or packaging }\end{array}$ \\
\hline 5. & $\begin{array}{l}\text { Price Audits Competitor } \\
\text { Shops }\end{array}$ & $\begin{array}{l}\text { It shows comp anies to see a snap shot of how their present pricing comp ares with that of their identified } \\
\text { competitors in consumers mind map. }\end{array}$ \\
\hline 6. & $\begin{array}{l}\text { Neuro-Economic } \\
\text { Profiling }\end{array}$ & to capture not only what happened, but how that experience emotionally impacted the consumer. \\
\hline 7. & $\begin{array}{l}\text { Customer and Employee } \\
\text { Online Climate Surveys }\end{array}$ & $\begin{array}{l}\text { Customer or Employee Climate Survey"s provide a picture of organization's needs, and can be used to } \\
\text { solicit employee customer opinions on a variety of issues such as the company's success in } \\
\text { communicating its mission to employees, }\end{array}$ \\
\hline 8. & SocialMedia Monitorng & $\begin{array}{l}\text { Monitoring (brands, product labels, product names), major competitors and str ategic issues (brand values } \\
\text { such as sustainability, innovation and key market issues such as price-performance ratio, friendliness) on } \\
\text { social media chamels as Blogs and micro blogs like Twitter, Social networking sites like Face book, or } \\
\text { LinkedInNetlog, Forums, especially relevant professional forums, Content communities such as YouTube } \\
\text { or Flickr, Classic online media and Wikipedia }\end{array}$ \\
\hline
\end{tabular}

\section{Myster Shopper Instrument - Mystery Shop Auditors}

A successful mystery shop program should include skilled design, easy administration, advanced technology, and importantly: first rated shoppers. Mystery Shopping concept revolve around its instrument i.e. its trained professionals also termed as mystery shopping auditors:

These Auditor minute observe every details of the shopping paradigm to get and insight of the experience generated .Thus companies train their professionals to become a competent - Shop Auditors. 
6.1 Key principles of Shop Auditor to work for Mystery Shopper must,

1. Relevant

a. do the scenarios test what staff have actually been trained to do?

b. is performance being measured against specific customer service standards?

2. Credible

a. are the scenarios realistic and convincing, not too slick or over-rehearsed?

b. do the 'shoppers' match the profile of customers as far as possible?

3. Practical

a. are the scenarios relatively brief and straightforward, not unduly complex?

b. are the scenarios simple enough to ensure accurate recording after the event?

4. $\underline{\text { Safe }}$

a. have steps been taken to ensure that 'shoppers' are not put in situations which compromise their personal safety?

b. would you be prepared to do what you are asking the 'shoppers' to do?

\section{Training For Shop Auditors}

These Instruments of Mystery shopping are trained on distinct parameter to be efficient enough to tap the customer intelligence. Training is associated with evaluation channel. Each channel is connected with each set of training.
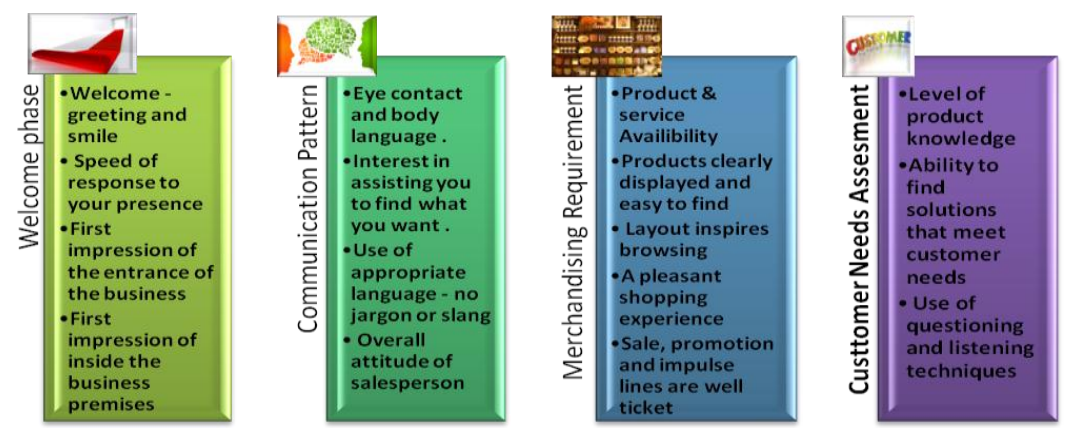

Figure 2: Evaluation Channels

\section{Training Module Format}

1. Welcome phase : Professional observation power is improvised .on each criteria of shop entrance or first interface with brand, employee or service

2. Communication Pattern : Professional Communication Training techniques accurately measure service levels and selling skills against a set of customer service and sales performance standards, tailored specifically for each business. Shop Auditors are trained on both verbal and non verbal communication pattern to tap each customer service note. They replicate the intelligence of regular patron. thus keen training is given on observations on :

a) Greeting at the welcome and end.

b) Measure for facial expression and voice tone of service provider.

c) High proficiency on language to go towards a well versed laddering exercise for individual service or product.

d) Reaction tapping for tolerance of employees at critical incidences.

e) Use of appropriate language - no jargon or slang.

f) Overall attitude of salesperson.

3. Merchandising Requirement: merchandising is really about displaying a product, service or concept to its best advantage. It focuses on the physical evidence of the Product \& service. Availability of the product stand first then comes the subsequent several components of it. A shop auditor should also need to be well versed with these components to identify the indifference among benchmarking and reality.

Shop auditors are made familiar with the tool of visual merchandising, relating from :

Availability, Display, ambience, décor, lightning, fragrance comfort zone ,signals and notes , display boards , announcement, employee attitude and behavior. Over all specification on:

- Products clearly displayed and easy to find

- $\quad$ Layout inspires browsing 
- A pleasant shopping experience

4. Customer need Assessment: Next integrate part of the Shop Auditors training is comprehended with the product training, relating to the vast knowledge about the product and the service of the brand. As today's patrons are highly technology oriented and thus social media connect customer gather huge information about the product or the service before entering the shop premises. Thus it is a requirement for the shop auditor also to be well versed with the details and develop an understanding of a goods or service that might include having acquired information about its application, function, features, use and support requirements. Summing up to the components as

- Level of product knowledge

- $\quad$ Ability to find solutions that meet customer needs

- Use of questioning and listening techniques

\section{Ethics In Mystery Shopping}

Mystery shopping organizations advise that their research should only be used for employee incentive programs, and that punishment or firing is an inappropriate use of mystery-shopper data .Thu most importantly these shopper are also made aware about the guideline and norms about the ethical code of conduct of mystery shopping as the major guideline issued by the Trade Organization for Mystery Shopping Providers, MSPA has defined a Code of Professional Standards and Ethics Agreement for Mystery Shopping Providers and for Mystery Shoppers. Few guidelines as mentioned are;

- Names of staff members or their identities through video, tape etc. may only be revealed if staff have been informed about this beforehand.

- Not to go of any illegal activity in process of mystery shopping.

- Clear Communication: not using any filthy statement and words.

- Professionalism: perform all shops with honesty and integrity.

- Secrecy of the data collected should be maintain and not to be used for putting blemish on the image of the brand.

\section{Managerial Implication}

Thus when we focus our needle to core of Mystery shopping we find today it has become a tool to Customer intelligence management. Our Intellectual customer can't be bluffed around today and to match their competency or to be an stimulated customer, mystery shop auditor need to be professionally trained. As the mystery shopper's are the silent partner in the pursuit of truth. Thus their training, knowledge, intellect do count in attaining mystery shopping industry to its aim .

We would like to point out that mystery shopping should be used in an open and transparent way. A reason for this lies in the fact that the communication of the use of mystery shopping throughout the whole organization already gives a signal to pay more attention to the perception of real customers. In this context the success of a mystery shopping study is decisively dependent on the genuine involvement of the management.

With this need for more comprehensive information shoppers are called upon to focus on the training of their various attributes. They must have detailed and comprehensive information about the policies adopted by the service providers and products in order to communicate their competitive advantage. It is a well-known fact, that more and better information provided by shoppers can reduce the risk as well as help differentiate the customers need. The skills and competencies necessary can thereby be communicated and trained in special courses and workshops, but also through new media, computer software, intranet, or instructional videos.

\section{References}

[1]. Verma , A. (2008). Mystery Shopping- An introduction.The ICFAI University Press

[2]. Dwek, R. (1996), "Magic of mystery shopping", Marketing, Vol 17, pp. 41-44. Erstad, M. (1998), "Mystery shopping programmes and human resource management", International Journal of Contemporary Hospitality Management, Vol 10 No 1, pp.34-38.

[3]. European Society for Opinion and Marketing Research (ESOMAR) (2005), "Mystery Shopping Studies", available at http://www.esomar.org/web/show/file/id=47043/filename=ps_cg_mysteryshopping.pdf/page=43240

[4]. Finn, A. and Kayandé, U. (1999), "Unmasking a Phantom - A Psychometric Assessment of Mystery Shopping", Journal of Retailing, Vol 75 No2, pp. 195-217.

[5]. Guidelines for Mystery Shopping Research ( MRA)(2005)," MRS Code of Conduct Market Research Society,"www.mrs.org.uk/pdf/code of conduct.pdf

[6]. Shoppercritique services, "https://www.shopperscritique.com/focus-groups-guest-intercepts-2

[7]. Mystery Shopping Providers Association - www.mspa-ap.org

[8]. Brender-ilan,Y. and Shultz ,T. (2005)" Perceived fairness of the mystery customer method: Comparing two employee evaluation Pracctices". Employee Responsibilities and Rights Journal, vol.17 (4), pp. 231-243.

[9]. Kira ,M.P,( 2005) “Ghost Shopping”. Http://www.indiamba.com 